\title{
‘Tolerable Intolerance': Protestantism, Sectarianism and Voluntary Hospitals in Late-nineteenth-century London
}

\author{
CARMEN M. MANGION * \\ Birkbeck, University of London, Department of History, Classics and Archaeology, Malet Street, \\ London WC1E 7HX, UK
}

\begin{abstract}
This article interrogates the complicated understanding of sectarianism in institutional cultures in late-nineteenth-century England through an examination of the practice of religion in the daily life of hospital wards in voluntary hospitals. Voluntary hospitals prided themselves on their identity as philanthropic institutions free from sectarian practices. The public accusation of sectarianism against University College Hospital triggered a series of responses that suggests that hospital practices reflected and reinforced an acceptable degree of 'tolerable intolerance'. The debates this incident prompted help us to interrogate the meaning of sectarianism in late nineteenth-century England. How was sectarianism understood? Why was it so important for voluntary institutions to appear free from sectarian influences? How did the responses to claims of sectarian attitudes influence the actions of the male governors, administrators and medical staff of voluntary hospitals? The contradictory meanings of sectarianism are examined in three interrelated themes: the patient, daily life on the wards and hospital funding. The broader debates that arose from the threat of 'sectarianism in hospital' uncovers the extent to which religious practices were ingrained in hospital spaces throughout England and remained so long afterwards. Despite the increasing medicalisation and secularisation of hospital spaces, religious practices and symbols were embedded in the daily life of voluntary hospitals.
\end{abstract}

Keywords: Sectarianism, Voluntary hospitals, Philanthropy, Church of England, Anglo-Catholics, Anglican sisterhoods, Nursing history

* Email address for correspondence: c.mangion@bbk.ac.uk

I have benefited greatly from conversations with Anne Summers about hospitals and sectarianism which have helped develop my thinking on this subject. Many thanks go also to Joanna Bourke and Sue Hawkins who read early versions of this work. Clare Midgley, Lucy Bland, Katharina Rowold, Cornelie Usborne and Krisztina Robert gave important suggestions and support during the process of revising this article. I am grateful for the valuable feedback of anonymous journal reviewers. I also appreciated presenting this work at the Voluntary Action History Society conference and The Centre for the Social History of Health and Healthcare at Glasgow Caledonian University; audiences were very generous with their comments. I owe a special thanks to the All Saints Sisters of the Poor, and especially archivist Revd Sister Margaret Anne McAlister ASSP for allowing me access to their private archives. 


\section{Introduction}

In May 1885, the Prince of Wales, at a fundraising event for the University College Hospital, feted the nursing staff, the 'ladies of All Saints' Home', proclaiming that 'the devotion, the zeal, the energy, which they have displayed in these important duties has received the greatest praise and commendation from all those who are connected with the Hospital'. ${ }^{1}$ The following month, these plaudits were forgotten. A short communiqué from 'A Life Governor' appeared in the editorial column of the Daily News under the title 'Sectarianism in Hospital':

I have always been brought up to believe that if there was an unsectarian institution in the world it is University College, in Gower-street, and the institutions affiliated to it. . . A short time since a complaint reached my ears that a young lady who wished to be trained as a professional nurse had applied for admission to University College Hospital as a probationer, that she had been approved in every respect as a fit and proper person, but that the question was eventually asked whether she belonged to the Church of England, and as she replied that she was a Nonconformist she was at once refused. ${ }^{2}$

This letter sparked a flurry of correspondence and articles in the Daily News, The Times, The Spectator, The Saturday Review, The Charity Record, The British Medical Journal and The Lancet that spanned almost a full year and included over twenty correspondents: medical doctors, hospital administrators, clergymen, university old boys as well as former and current staff of University College Hospital (UCH). Various tensions were at play, the most obvious being the religious proclivities of the Anglican sisters managing the nursing in voluntary hospitals, but this was undergirded by issues regarding strains within the Church of England amongst Anglicans (broad church, evangelicals and Anglo-Catholics) and the relationship between Protestants (Anglicans and nonconformists).

The ongoing tensions centring on Church of England political and religious privilege remained live even after the 1828 Test and Corporation Act allowed nonconformists to enter more fully into British public life. Openly competing religious rivalries and intolerances were present throughout the slow dissolution of Anglican privilege, which included: the removal of religious tests at Oxford and Cambridge Universities (1854 and 1856), the abolition of church rates (1868) and the permission for nonconformist burial service in parish churchyards (1880). Controlling schooling was significant to the future success of any denomination, particularly given the analysis of the 1851 Religious Census that suggested all forms of Protestantism were struggling to attract working-class adherents. ${ }^{3}$ Nonconformists were particularly excised regarding the 'education question' and subsequent debates on a national system of education which they hoped to be 'managed and administered locally in a democratic way'. The religious dimensions of the Education Bill of 1870 were identified as a struggle against 'sectarian' education. ${ }^{4}$ Into the 1880 s, it was the disestablishment of the State Church that was the oft debated component of the general election of 1885 and discord between Anglicans and Nonconformists

1 'The "Royal" University College Hospital', The Charity Record, Hospital Times, Philanthropic News, and Official Advertiser, V, 112 (21 May 1885), 164.

2 'Sectarianism in Hospitals', Daily News, 12 June 1885. The University College London was founded in 1826 as a secular (meaning non-religious) alternative to Oxford or Cambridge (they required membership to the Church of England for either admission or graduation). Negley Harte and John North, The World of UCL, 1828-1990 (London: UCL, 1991), 12.

${ }^{3}$ Horace Mann, Census of Great Britain, 1851: Religious Worship in England and Wales (London: G. Routledge and Co., 1854), 93.

${ }^{4}$ Eugenio F. Biagini, Liberty, Retrenchment and Reform: Popular Liberalism in the Age of Gladstone, 1860-80 (Cambridge: Cambridge University Press, 1992), 197-8, 206. 
frequently aired in the press. ${ }^{5}$ The 'religious question' was thus an integral component of the political landscape at the time when 'A Life Governor' aired his grievance against University College Hospital.

This article interrogates the complex nature of sectarianism in institutional cultures in late-nineteenth-century England through an examination of the role of Protestantism in the daily life of hospital wards in voluntary hospitals. ${ }^{6}$ Voluntary hospitals prided themselves on their identity as philanthropic institutions free from sectarian practices. The public accusation of sectarianism in 1885 and the debates it provoked suggest that religious practices in hospital spaces were acceptable and the privileging of particular denominations reflected and reinforced a degree of 'tolerable intolerance'. ${ }^{7}$ Three interrelated themes, the patient, daily life on the wards and hospital funding, are used to examine the contradictory meanings of sectarianism.

Studies of nineteenth-century philanthropy address the early influence of Christianity noting that the foundations of many hospitals were motivated not only by charitable impulse, but also by evangelical objectives. ${ }^{8}$ Religion has tended to be relegated to nursing history falling in line with gendered ideas of womanhood. ${ }^{9}$ Historian Anne Summers observes that voluntary hospitals developed 'within the framework of Anglican charity and ministry'. Her work on the early nursing movements of the nineteenth century argues that nurses were propelled by an evangelising impulse and utilised medical care as a means to Christianise by word and deed. ${ }^{10}$ More influential to nursing praxis were the Anglican sisterhoods that emerged out of the Oxford Movement. ${ }^{11}$ Others have argued

\footnotetext{
${ }^{5}$ Alan Simon, 'Church Disestablishment as a Factor in the General Election of 1885', The Historical Journal, 18 (1975), 791-820. See also Gerald Parsons, 'Liberation and church defence: Victorian church and Victorian chapel', in Gerald Parsons (ed.), Religion in Victorian Britain: Controversies (Manchester: Manchester University Press, 1988), 147-65.

${ }^{6}$ Sectarianism remains under-theorised. Much of the debates on sectarianism have been informed by religion, but broadly defined sectarianism exists whenever communities within a shared culture identify themselves as divided. For an example of medical sectarianism, see John Harley Warner, 'Medical sectarianism, therapeutic conflict, and the shaping of orthodox professional identity in antebellum American medicine', in W.F. Bynum and Roy Porter (eds), Medical Fringe and Medical Orthodoxy, 1750-1850 (London: Croom Helm, 1987), 234-60. The recent work of Keith Roberts defines sectarianism not only through divisions within a community but also suggests that sectarian clashes are multi-dimensional and often involve economics, identities and political or social privileging. Keith Daniel Roberts, Liverpool Sectarianism: The Rise and Demise (Liverpool: Liverpool University Press, 2017), 19-20.

7 'Tolerable Intolerance', The Saturday Review (19 December 1865), 799.

${ }^{8}$ Frank Prochaska, The Voluntary Impulse: Philanthropy in Modern Britain (London: Faber and Faber, 1998), 21-5, and Christianity and Social Service in Modern Britain: The Disinherited Spirit: (Oxford: Oxford University Press, 2006); Kathleen E. McCrone, 'Feminism and Philanthropy in Victorian England: The Case of Louisa Twining', Canadian Historical Association, Historical Papers (1976), 123-139; Brian Harrison, 'Philanthropy and the Victorians', Victorian Studies, 9 (1996), 353-74, 358; Kathleen Heasman, Evangelicals in Action (London: Geoffrey Bles, 1962), 11; Kathleen J. Heasman, 'The Medical Mission and the Care of the Sick Poor in Nineteenth-Century England', The Historical Journal, 7 (1964), 230-45.

9 Anne Marie Rafferty, 'Tiptoeing Towards a History of Nursing in Europe', Nursing History Review, 22 (2014), $107-13$.

${ }^{10}$ Anne Summers, 'The cost and benefits of caring: nursing charities, c. 1830-c. 1860', in Jonathan Barry and Colin Jones (eds), Medicine and Charity before the Welfare State (London: Routledge, 1991), 138. See also Sioban Nelson, Say Little, Do Much: Nurses, Nuns, and Hospitals in the Nineteenth Century (Philadelphia, PA: University of Pennsylvania Press, 2001).

${ }^{11}$ For example, Summers, ibid., 144-5; Carol Helmstadter and Judith Godden, Nursing Before Nightingale, 1815-99 (Farnham, Surrey: Ashgate, 2011), xii-xiii. The Oxford Movement initiated by Edward B. Pusey (1800-82) and John Henry Newman (1801-90) sought to re-Catholicise the Church of England through a shift in doctrinal thinking and liturgical practices. Carol Helmstadter maintains that St John's House was the first formal training institute that provided nurses 'systematic hospital training' which included a clinical education.
} 
that sisterhoods took on the 'secular spirit of medical modernization' despite a focus on 'spiritual concerns'. ${ }^{12}$ Criticism levied on the sisterhood structure of nursing has been linked to the 'self-regulation and trained expertise' of religious sister-nurses and their potential threat to masculine medical authority. ${ }^{13}$ Sectarianism can be seen in high relief in the development of an Anglican diocesan nursing association in Lichfield which threatened Evangelical Protestants ${ }^{14}$ or in the examination of the German Hospital's Lutheran chaplain and deaconess-nurses accused of proselytisation. ${ }^{15}$

This article decentres this gendered linking of religion with nursing, to rethink the place of religion more broadly, in hospital institutional cultures which were managed by men. Both R.J. Morris and Theodore Koditschek use the wider lens of associational culture to point to middle-class charity linked to, in Koditschek's words, an 'individualistic, salvation-centred' preoccupation. ${ }^{16}$ Religious institutions were intrinsic to the charitable and financial underpinning of voluntary hospitals. ${ }^{17}$ Denominational religious tensions were embedded into the fabric of Victorian life, ${ }^{18}$ and were not only gendered female. More subtle is the 'deeply sectarian tinge' that Martin Gorsky detects within philanthropy. ${ }^{19} \mathrm{He}$ noted that historians of voluntarism have 'tended to minimise impact of party and sectarian fissures'. Voluntarism was a badge of religious identity and sectarianism influenced voluntary associations beyond simply competition..$^{20}$

One such 'sectarian fissure' occurred at UCH. This reframing, which investigates institutional cultures, reveals the role of religion in voluntary hospitals and uncovers late nineteenth-century understandings of 'sectarianism'. ${ }^{21}$ This article makes use of the

Carol Helmstadter, 'Building a New Nursing Service: Respectability and Efficiency in Victorian England', Albion, 35 (2003), 591-2. The sister-nurses of St John's House (1848) managed and nursed in King's College Hospital (1856-85) and Charing Cross Hospital (1866-89).

12 Robert Dingwall, Anne Marie Rafferty and Charles Webster, An Introduction to the Social History of Nursing (London: Routledge, 1988), 29.

${ }^{13}$ Carol Helmstadter, 'The First Training Institution for Nurses: St John's House and 19th Century Nursing Reform Part II: The Impact of St John's House on 19th Century Nursing Reform', History of Nursing Society Journal, 5 (1994/5), 11-13. Also, Judith Moore, A Zeal for Responsibility: The Struggle for Professional Nursing in Victorian England, 1868-83 (Athens, GA: University of Georgia Press, 1988).

${ }^{14}$ Stuart Wildman, "Nursing and the Issue of "Party" in the Church of England: The Case of the Lichfield Diocesan Nursing Association', Nursing Inquiry, 16 (2009), 94-102.

${ }^{15}$ Christiane Swinbank, 'Medicine, philanthropy and religion: selective intercultural transfers at the German Hospital in London, 1845-1914', in Stefan Manz, Margrit Schulte Beerbühl and John R. Davis (eds), Migration and Transfer from Germany to Britain 1660-1914 (Munich: K.G. Saur, 2007), 119-30, 128-30.

16 R.J. Morris, Class, Sect and Party: The Making of the British Middle Class Leeds: 1820-50 (Manchester: Manchester University Press, 1990); Theodore Koditschek, Class Formation and Urban-industrial Society: Bradford, 1750-1850 (New York: Cambridge University Press, 1990), 252.

${ }^{17}$ Keir Waddington, Charity and the London Hospitals, 1850-98 (Woodbridge, Suffolk: The Boydell Press, 2000), 25-6. John Woodward, To Do the Sick No Harm: A Study of the British Voluntary Hospital System to 1875 (London: Routledge and Kegan Paul, 1974), 20.

18 There is a broader historiography of anti-Catholicism that addresses these histories. Robert J. Klaus, The Pope, the Protestants, and the Irish: Papal Aggression and Anti-Catholicism in Mid-Nineteenth Century England (London: Garland Publishing, 1987); Michael Wheeler, The Old Enemies: Catholic and Protestant in NineteenthCentury English Culture (Cambridge: Cambridge University Press, 2006); John Wolffe, The Protestant Crusade in Great Britain, 1829-60 (Oxford: Clarendon Press, 1991).

${ }^{19}$ Martin Gorsky, Patterns of Philanthropy: Charity and Society in Nineteenth-century Bristol (Woodbridge, Suffolk: The Boydell Press, 1999), 79.

${ }^{20}$ Gorsky, ibid., 34, 116, 195-96.

${ }^{21}$ Holloway, Likeman and Mayhew allude to this incident, but do not analyse it through the lens of sectarianism. S.W.F. Holloway, 'The All Saints' Sisterhood at University College Hospital, 1862-99', Medical History, 3 (1959), 151; Janet Likeman, 'Nursing at University College Hospital, London, 1862-1948: From Christian Vocation to Secular Profession' (unpublished PhD thesis, Institute of Education University of London, 2002), 
numerous letters to the editor printed in the national, local and medical press. These letters written by hospital administrators, medical men, clergy and benefactors, all men embedded in these institutional cultures, addressed not only the 'facts' of this incident but also their attitudes towards religion in the medical marketplace. ${ }^{22}$ The archives of the UCH, the Metropolitan Hospital Sunday Fund, the Burdett Archives and the Community of All Saints Sisters of the Poor contain correspondence and meeting minutes which explicate factors not published in the press. A close reading of this published and administrative material allows a shift in focus away from the questions of nursing-related issues (gendered authority, professionalisation and the decline of sisterhood nursing ${ }^{23}$ ) to a focus on daily life on the hospital wards and claims of sectarianism.

The Anglican religious community at the centre of this furore was the Community of All Saints Sisters of the Poor founded by Harriet Brownlow Byron (1818-87) and the Reverend William Upton Richards (1811-73) in 1851. All Saints was a fast growing congregation, opening twenty-one convents in Britain in the nineteenth century while branching out to the United States, South Africa and India; over four hundred sisters worked in these institutions. ${ }^{24}$ In their first ten years, they managed St Elizabeth's Home for incurables on Mortimer Street, attended to a dispensary in Marylebone Passage and nursed the poor in their homes. ${ }^{25}$ The link to University College Hospital began in 1859 when Byron requested permission for sisters to obtain hospital nursing experience at $\mathrm{UCH} .{ }^{26}$ Their nursing was reported as 'far more efficient than under any former system, and is also more pleasant to the patients', ${ }^{27}$ and in 1862 they were given a contract to supervise the nursing at UCH. Like many voluntary hospitals, they offered nurse training. The letter from the 'Life Governor' and the tumult that ensued led to the Anglican All Saints Sisters accepting nonconformists for nurse training. ${ }^{28}$ The relationship between the

43-48; Peter Mayhew, All Saints: Birth and Growth of a Community (Oxford: Society of All Saints, 1987), $108-11$.

${ }^{22}$ For more on the impact of the popular press on public opinion, see Aled Jones, Powers of the Press: Newspapers, Power and the Public in Nineteenth-Century England (Abingdon: Ashgate Press, 1996) and Hannah Barker, Newspapers, Politics and English Society, 1695-1855 (London: Longman, 2000).

${ }^{23}$ Helmstadter and Godden, op. cit. (note 11), 123-89. See also Moore, op. cit. (note 13) and Summers, op. cit. (note 10).

${ }^{24}$ Susan Mumm (ed.), All Saints Sisters of the Poor: An Anglican Sisterhood in the Nineteenth Century (Woodbridge, Suffolk: The Boydell Press, 2001), xii-xiv. Their stated objectives were for 'reception and maintenance of Incurables, of aged and infirm persons in destitute circumstances, and Orphans'. 'The Statutes of the Sisters of the Poor', Mumm, idem, 88. Many of the medical institutions run by Catholic and Anglican women religious were targeted at the respectable poor law class with non-acute medical conditions. Carmen M. Mangion, " "Meeting a well-known want": Catholic specialist hospitals for long-term medical care in late nineteenth-century England and Wales', in Christopher Bonfield, Jonathan Reinarz and Teresa Huguet-Termes (eds), Hospitals and Communities, 1100-1960 (Oxford: Peter Lang, 2013), 239-61.

25 'Memories of Sister Caroline Mary', in Mumm, ibid., 9-10. Mumm suggests that this memoir was written around 1920.

${ }^{26}$ University College Library Archives (UCLA), UCH OFF/MIN 4/2 December 1859, 149. The General Committee of University College Hospital ran the administrative affairs of the hospital, often seeking advice from sub-committees (the Medical Committee and the House and Finance Committee) that managed more routine matters.

${ }^{27}$ UCLA, College Collection A-D, 1861-62 Annual Report, 10.

28 The change in policy occurred in 1889 , four years after a letter was received from the Wesleyan Conference Committee of Privileges (this committee was founded in 1803 to protect nonconformist rights under the 1689 Act of Toleration) complaining that a Methodist nurse probationer was rejected because she was not an Anglican. This time, the General Committee acted quickly. After a brief correspondence with the Mother Superior of All Saints, the General Committee responded to the Committee of Privileges indicating that nonconformists would be accepted as probationers. UCLA, UCH OFF/MIN 4/6 10 April 1889, 459-60. This letter was copied into the 
sisterhood and the hospital remained collaborative, but financial matters and, probably more importantly, the desire of the medical staff and the governors to place nursing under the direct control of the hospital led to the departure of the All Saints Sisters from UCH in $1898 .{ }^{29}$ Historian Steven Holloway asserts that 'All Saints had outlived its usefulness at U.C.H. . ${ }^{30}$ There is some truth to this. By the 1890 s, nurse-training schools were producing qualified nurses and the benefits of the 'contract system' were less evident. Importantly, hospital managers and medicos wanted direct administrative control over the nursing staff. Sisterhood nursing had outlived its usefulness in voluntary hospitals.

The following three sections examine how sectarianism was employed by male correspondents and hospital governors, General Committee members and medical staff in regard to patients, the daily life on the wards and all-important hospital funding. ${ }^{31}$

\section{The patient}

The UCH General Committee's initial response to the accusation of sectarianism was denial. They defined sectarianism as a patient's freedom to choose their own religious minister and practice their faith, and focused on institutional safeguards against proselytisation. ${ }^{32}$ The General Committee referenced the memorandum of agreement between UCH and All Saints. Clause nine stated:

It is expressly understood as an essential condition of the agreement, that no one connected with the Home [All Saints] should in any way, by word or deed, or by the distribution or withholding of Books, interfere with, or attempt to influence the religious opinions of the patients. ${ }^{33}$

The main enforcer of Clause nine was Henry Stebbing (1788-1883), ${ }^{34}$ hospital chaplain from 1834 to 1879 , a 'very strict Churchman' who insisted that 'the sisters never interfered with his duties'. ${ }^{35}$ Sister Catharine Williams (1817-1917) in her old age remembered Stebbing

walked about the Hospital in his Gown, \& had Matins on one of the long Wards on Sunday. He often came into one of the Wards as dinner was placed on the table, \& when asked to say Grace repeated a long prayer. ${ }^{36}$

General Committee minutes. Unfortunately, the letters to and from the All Saints Sisterhood were not included in the minutes, nor has a copy been found in the All Saints Sisterhood Archives. Founder Harriet Brownlow Byron would have been the mother superior in 1885, the year the first letter from the 'Life Governor' appeared in the press. She died in 1887, and was replaced as mother superior by Mother Caroline Mary Short, who may have been more amenable to a change.

${ }^{29}$ Holloway points to numerous reasons for their departure, putting most credence on the failure of the All Saints Sisterhood to modernise its nursing practices (Holloway, op. cit. (note 21), 153-4). Helmstadter and Godden (op. cit. (note 23), 173-80) disagree with this interpretation.

${ }^{30}$ Holloway, op. cit. (note 21), 153.

31 Nurse historian Janet Likeman maintains that the uproar around the 1885 incident had three elements: finance, faith and nurse training, but this article argues that what underpins this episode was the issue of sectarianism. Likeman, op. cit. (note 21), 43.

32 Throughout this public dispute, patient voices were invisible, as were the voices of the All Saints nursingsisters.

33 UCLA, UCH OFF/MIN 4/2 25 April 1862, 311.

${ }^{34}$ Arthur Burns describes him as an evangelical whose 'complicated position' was 'incompatible with evangelical partisanship, not least in an overwhelming commitment to religious tolerance'. Arthur Burns, 'Stebbing, Henry (1799-1883)', Oxford Dictionary of National Biography (Oxford University Press, 28 May 2015 online version).

35 'The Nursing Question', The Times, 11 August 1885, 3.

36 'Memories of an Old Woman' in Mumm, op. cit. (note 25), 56-7. Sister Catharine Williams wrote these memories in 1907 when in her 80s. Matins is part of the morning liturgy. 
She emphasised Stebbing was 'very protestant', inferring an orthodoxy in his Anglicanism and, by implication, his resistance to Anglo-Catholicism. Stebbing was seen as an independent monitor who would be vigilant in his surveillance of the All Saints Sisters.

'The Old House Surgeon' from UCH introduced the elephant in the room by questioning the Anglican credentials of the All Saints Sister-nurses:

If the sisterhood who now have possession of University College Hospital really held bona-fide Church of England doctrine there would be far less objections to their ministrations than is now felt by many of the old supporters of this originally thoroughly unsectarian institution. ... ${ }^{37}$

The Oxford Movement had proved contentious within the Church of England and some regarded Anglican sisterhoods as too closely aligned with Roman Catholicism. ${ }^{38}$ The Christian cross was yet another symbol that could reside on either side of the sectarian divide. 'The Old House Surgeon' revealed that 'pictures with large crosses in them' were hung on the walls of some of the wards. ${ }^{39}$ In reply, several on the staff at UCH jumped to the defence of the sisters: reinforcing their effectiveness as competent nurses, their 'social duty' and emphasising their obedience to the chaplain. Dr Edward Shoppee retorted:

I never once saw the sisters make their social duty subservient to their religious exercises, but I can affirm that the sister of the ward (Sister Emily Mary) made it a great point that the nurses had the ward ready for the Chaplain appointed by the General Committee.

Shoppee's comments implied the chaplain's role and function was sanctioned and represented the acceptable face of Christianity in the hospital. Interestingly, Stebbing's role as chaplain in this 'godless institution' was unquestioned. ${ }^{40}$ As a member of the establishment, his religious identity was not seen as a threat to a patient's religious liberty. As will be discussed later, his role at UCH points to the embedded nature of an orthodox Anglican Christianity in the daily life of voluntary hospitals. The General Committee underscored that patients were free to consult ministers and visitors of their own religious denomination. All wards contained a placard declaring:

Every patient is allowed to have the attendance and ministrations of any minister of religion, or of any Scripture reader, or other authorised representative of such minister whom he or she may prefer. ${ }^{41}$

Clause nine plus this signage was meant to reinforce and display the non-sectarian ethos of the hospital and their commitment to respect the different spiritual needs of their patients. The General Committee in their response to the accusation of sectarianism pointed to explicit and implicit controls in place to avoid religious interference.

Partisan press editorials, however, continued to link sisterhood nursing to patient proselytisation. One 'Hospital Secretary' writing in The Times argued that the All Saints Sisters should not be nursing at UCH:

\footnotetext{
The plain question is this - (1) are poor people taken to a hospital to receive surgical and medical attention or to be kept in bed while, whether they like it or not, a number of earnest believers in some particular form of creed endeavour to convert them to that creed; (2) are hospital nurses employed in hospitals to carry out the

37 'The Nursing Question', The Times, 6 August 1885, 3.

38 John Shelton Reed, Glorious Battle: The Cultural Politics of Victorian Anglo-Catholicism (Nashville: Vanderbilt University Press, 1996), 201.

39 'The Nursing Question', The Times, 11 August 1885, 3.

${ }^{40}$ University College London was known as that 'godless institution of Gower Street'. François Guesnet, Cécile Laborde and Lois Lee (eds), Negotiating Religion: Cross-Disciplinary Perspectives (London: Routledge, 2013), xxii-xxiii.

41 'The Nursing Question', The Times, 8 August 1885, 11.
} 
doctor's directions to alleviate pain and, for the time being, to brighten the lives of those in their charge, or are they employed as the emissaries of some religious sect or sisterhood (probably no better, and maybe worse, than most others) to undertake nursing merely as a pretext for forcing their doctrines on those who are unable to show their disapproval of the proceeding by getting up and walking away, and those who may possibly have a right to consider their own form of religion as good as that represented by the nursing sisterhood? ${ }^{42}$

Sister-nurses were portrayed as religious zealots whose aim was to proselytise helpless patients. The 'Hospital Secretary' did not limit the problem of religious coercion to Anglican sisterhoods; he saw women falling prey to their own religious impulses as an endemic problem:

among a large number of nurses trained in the hospital from which I write[,] the most unsatisfactory are those who come impressed with the paramount necessity of exerting a religious influence over the patients. They not only frequently neglect their proper duties as nurses to the patients while making arrangements for prayer meetings in the wards or while reading religious books, but they also do actual physical harm by exciting those who ought to be kept perfectly calm. Of course there are at times deeply religious women in our hospital to whom my remarks do not apply, but from the experience of the matron and myself they are an exception to the rule. ${ }^{43}$

This gendered critique of some of these so-called 'new nurses', professionally-trained nurses whose religious penchants interfered with patient care, has been reinforced by some nursing historians. Nursing historian Monica Baly claims this was a ubiquitous issue; she notes that Nightingale nurse leaders from St Thomas's 'were devoutly religious with strong sectarian biases. . . and all of them were not above proselytizing' ${ }^{44}$ Revisionist Sue Hawkins' prosopographical study of 'new nurses' questions this emphasis on religious motivation, convincingly arguing that most nurses saw nursing as employment, not as a means of evangelisation. ${ }^{45}$

Administrative governors and doctors engaged in this debate were not averse to religious practices on the wards; they declared Christian practices and material culture in hospital spaces were non-sectarian. The 'Hospital Secretary' acknowledged:

Nothing can be better than that a sick nurse who should be a good, kind, sympathetic, Christian woman, ready to pray with or read to a suffering patient, provided that her prayers and reading are of an unsectarian character. ${ }^{46}$

He was suggesting that certain prayers and readings, presumably those without particular doctrinal teaching, were acceptable to patients and 'unsectarian'. Though this appears contradictory, it reflects his understanding that Protestant Christianity was 'unsectarian'. He was not alone in thinking this way. Scholar Andrea Tanner has written that hospital visitors calling on children at Great Ormond Street Hospital were 'agents of maternal socialisation' teaching them to read, write and pray and thus bringing into hospital spaces an 'ad hoc education' that 'was resolutely Christian in character and content' ${ }^{47}$ Many Victorians considered this form of Christianity 'unsectarian'. Historian John Wolffe remarked that by the late-nineteenth-century Britain's 'official religion' was

42 'The Nursing Question', The Times, 13 August 1885, 3.

43 Ibid.

${ }^{44}$ Monica E. Baly, 'Florence Nightingale and the establishment of the first school at St Thomas's - Myth v Reality', in Vern Bullough, Bonnie Bullough and Marietta P. Stanton (eds), Florence Nightingale and her Era: A Collection of New Scholarship (London: Garland, 1990) 3-22, 17.

45 Sue Hawkins, Nursing and Women's Labour in the Nineteenth Century: The Quest for Independence (London: Routledge, 2010).

46 'The Nursing Question', The Times, 13 August 1885, 3.

${ }^{47}$ Andrea Tanner, 'Care, nurturance and morality: the role of visitors and the Victorian London children's hospital', in Graham Mooney and Jonathan Reinarz (eds), Permeable Walls: Historical Perspectives on Hospital and Asylum Visiting (New York: Rodopi, 2009), 81-110, 91, 97-8. Visiting societies were a common form of outreach of religious denominations. See Prochaska, op. cit. (note 8), 107-12. 
institutional and "characterized in broader terms as "Christianity"'. Wolffe affirmed that Christianity 'identified the dominant religious ethos of the whole society and culture' ${ }^{48}$ We see this ascendancy enacted in voluntary hospitals.

Much of this initial debate reflected a patient-centred definition of sectarianism which highlighted the practices that were intended to safeguard the religious faith of patients, denying that the University College Hospital was sectarian. Those opposing sisterhood nursing pointed to the gendered nature of religiosity. Female 'religious' nurses, Anglican sisters and even secular nurses were portrayed as ruled by their religious fervour, and thus unable to refrain from proselytisation. The hospital chaplain, though, in his official, paid capacity was not considered a threat to the religious sensitivities of the patients. Neither was the reading material he distributed or the prayers he said on the wards. The daily practice and symbols of religion on the wards were not questioned. This definition of sectarianism was about the freedom to practice one's denominational identity within hospital spaces. The hospital ward was not intended as a religion-free space. The daily life on the ward was replete with religious influences, from the chaplain employed by the hospital to the material culture (whether it was crosses on the walls or religious reading) in hospital spaces. Churchman John Tulloch (1823-86) claimed that religion was intrinsic to both private and public life; the idea that it would be removed from 'common national life' was anathema. ${ }^{49}$ Sectarianism defined in these discourses, with all its contradictions, was about freedom of religion, not freedom from religion. ${ }^{50}$

\section{Daily Life on the Wards: From a 'Nursing Question' to a 'Religious Question'}

The initial public response identified what was initially represented as the central issue behind the accusation of sectarianism: patient proselytisation. The discussion moved from an understanding of sectarianism that was patient-centred and identified as a "nursing question' to a much larger 'religious question' when the Metropolitan Hospital Sunday Fund and the Hospitals Association got involved. Both were stakeholders in maintaining the identity of voluntary hospitals as free from sectarian practices. In response to their queries regarding the hiring practices of $\mathrm{UCH}$, physician Charles Hare inquired into the nursing employment practices of other voluntary hospitals. ${ }^{51}$ His survey results, from twenty London hospitals, were discussed at the Annual General Meeting of the Metropolitan Hospital Sunday Fund in December 1885. ${ }^{52}$ Responses to Hare's survey indicated that, in two hospitals, nurses were required to be members of the Church of England.$^{53}$ An additional four hospitals required their nurses to be Protestant; two hospitals excluded Roman Catholic nurses explicitly; and five included a question on religious

48 Wolffe, op. cit. (note 18), 45.

49 John Tulloch, 'On Dogma and Dogmatic Christianity', The Contemporary Review, 23 (1 December 1873), 928.

${ }^{50}$ Mangion makes a similar statement on Catholic hospitals in England and Wales in " "To Console, to Nurse, to Prepare for Eternity": The Catho lic Sickroom in Late Nineteenth-century England', Women's History Review, 21(4), (2012), 657-72.

${ }^{51}$ UCLA, UCH OFF/MIN/4/6 14 October 1885, 76.

52 Unfortunately the minutes of this meeting only note 'A considerable discussion arose'. London Metropolitan Archives (LMA), CLC/123/MS30585/003, Council and Annual Meetings of Constituents (ie. General Meetings) minute book, 15 December 1885, 117. The meeting discussion was summarised in 'Hospital Sunday Fund', The British Medical Journal, 19 December 1885, 1,179.

53 Ibid. These were likely King's College Hospital and Charing Cross Hospital as they were managed by St John's House, an Anglican sisterhood. Only sixteen hospitals responded to questions on the religious denomination of nurse applicants and nineteen on religious services occurring in hospital spaces. 
denomination on the application form. Even 'lady pupils' (paying probationers) in some hospitals faced denominational requirements: ${ }^{54}$ two hospitals excluded Roman Catholics as lady pupils and one hospital required lady pupils be members of the Church of England. Religious devotions were enacted in hospital spaces; sixteen hospitals required their nurses to attend Divine Services. ${ }^{55}$ Hare's discoveries led him to conclude that if UCH was sectarian because of its nurse hiring practices, so were seventeen of the twenty hospitals he surveyed. Dr George W. Potter, a member of the Metropolitan Hospital Sunday Fund was so enraged by this conclusion that he initiated his own survey of London hospitals. His results, based on fifty responses, were presented at the General Meeting of the Hospitals Association on 17 March 1886. Potter's presentation centred on the question 'Is the Nursing at the London Hospitals Sectarian?'. He noted that in all but four voluntary hospitals there was no religious bar to nursing. He also found that forty-three hospitals regularly held Church of England 'simple and ordinary' religious services, with nurses, ward-sisters or matrons conducting family prayers on the wards in fourteen of these and Church of England chaplains conducting services in another fifteen. These were optional for patients in thirty-eight hospitals. The public nature of the prayers on an open ward would appear to negate any real option, but Potter did not find this worth noting. His selfcongratulatory conclusion: religion in voluntary hospitals 'was a ministering angel and not a militant theologian'. He believed that the 'least sectarian arrangement in English hospitals was the moderate ascendancy of the services of the English Church' ${ }^{56}$ Potter did not identify Anglican religious practices in voluntary hospitals as sectarian.

As sources, these two reports are problematic on a number of levels. First, the survey data and detailed analysis that supported Hare and Potter's statistics were not published and are not extant, so it is difficult to determine which hospitals were surveyed and what specific questions were asked. Second, and most importantly, Hare and Potter derive from their surveys contradictory conclusions despite some similarity in the findings. Notwithstanding these issues, several points can be explicated from these surveys in combination with corroborating evidence.

First, religious bars to nurse training were unquestioned and not out of the ordinary. Other evidence supports this. Cassell's Household Guide's listing for the British Nursing Association, which contracted nurses at the Royal Free Hospital, required applicants to be Protestant:

a satisfactory medical certificate as to health; good character, certified with a clergyman's testimonial; the age to be between twenty-five and forty; and membership of the Church of England, or of some Protestant communion. ${ }^{57}$

In addition, Anglican sisterhoods were not only engaged in exclusionary practices, but were also restricted by them. St Margaret's Sisterhood informed their postulants that they should obtain nurse training before entering the sisterhood, implying there might be difficulty in obtaining nurse training as a religious sister. ${ }^{58}$ One sister was rejected from

\footnotetext{
${ }^{54}$ All Saints did not require paying probationers training at the University College Hospital to belong to the Church of England. 'Hospital Nursing', The Lancet, 15 August 1885, 295.

55 'The Nursing Question', Daily News, 16 December 1885.

56 'The Question of Sectarian Nursing', The Lancet, 20 March 1886, 556. Similar details were also reported in 'The Hospitals Association', The British Medical Journal, 20 March 1886, 560-1, and The Charity Record, Hospital Times, Philanthropic News, and Official Advertiser, 15 April 1886, 122.

57 Cassell's Household Guide to Every Department of Practical Life Being: A Complete Encyclopadia of Domestic and Social Economy vol. II (London, [n.d. but probably 1880s]), 21.

58 The Society of St Margaret was an Anglican sisterhood founded in 1855 by Dr John Mason Neale.
} 
a hospital nurse-training programme because she wore a cross, a potent symbol of her Anglo-Catholicism. ${ }^{59}$ Roman Catholics and Jews had even fewer nursing opportunities. Roman Catholic women were not welcomed in some nurse-training programmes. One Roman Catholic probationer sent her rejection letter from King's College Hospital to The Nursing Record. Her Catholic faith disbarred her from nurse training. Editors suggested she apply to St George's Hospital, St Mary's, the Middlesex or Charing Cross Hospital, which were willing to accept Roman Catholics. In 1889, The Nursing Record noted: 'The sooner such ridiculous intolerance is buried, the better. ${ }^{60}$ In 1894, the Honorary Secretary of the Workhouse Infirmary Nursing Association wrote that, while they trained Roman Catholic nurses, there was 'increasing difficulty' in placing them as they were often refused employment by boards of guardians. ${ }^{61}$ Later that year The Nursing Record was 'besieged by applicants for information as to where Roman Catholic ladies could apply to be trained as Nurses' ${ }^{62}$ Such issues were reported on the pages of The Nursing Record until $1899 .{ }^{63}$ Religious bars to nurse training existed into the twentieth century. ${ }^{64}$

Second, some hospitals identified as 'Protestant' institutions. In some cases, the link to Protestantism was made explicit. Nurse Rogers, a probationer Catholic nurse, voiced concern upon the death of an unbaptised baby that had died in Lambeth Infirmary. Her comments convinced one board guardian, Miss Love, that her doctrine [was] so unscriptural, and that it was not desirable that a Protestant institute should be obliged to have a Roman Catholic Nurse'. Nurse Rogers remained at the Lambeth Infirmary despite the six guardians who opposed her appointment. ${ }^{65}$ More often, the link to Protestantism was implicit, and made through daily hospital practices. Both Hare and Potter point to the everyday regime of patients and nurses in some hospitals. Potter acknowledged that in eleven hospitals, all convalescent patients were required to attend services. In the remaining hospitals, Roman Catholics and nonconformists were excused. ${ }^{66}$ Prayers were read in the wards each morning by a nurse at St Bartholomew's and the London Hospital. ${ }^{67}$ Dr Hare's survey noted that Church of England services were held in nearly all twenty hospitals he surveyed. Forty-three of Hare's fifty hospitals regularly held religious services in the hospital; attendance was compulsory for some hospital staff. As previously mentioned, sixteen of Potter's sample of twenty hospitals required nurses to attend Divine Services. ${ }^{68}$ In the 1890s, King's College Hospital (by this time, the nursing was no longer

\footnotetext{
59 'The Statutes of the Sisters of the Poor', 18 January 1859, in Mumm, op. cit. (note 24), 88-9.

${ }^{60}$ The Nursing Record, 28 February 1889, 139; idem, 1 August 1889, 74. In 1885, Roman Catholics and nonconformists were steered towards The London, the 'most unsectarian of hospitals' according to The Church Times, 5 August 1885.

${ }^{61}$ The Nursing Record \& Hospital World, 3 November 1894, 294. Italicised as in original text.

62 ibid.

63 Author's review of issues of The Nursing Record.

${ }^{64}$ Roy Wake, in his history of the Nightingale Training School, noted that even in the 1950s and 1960s, Catholic nurses were told that their future advancement was limited at St Thomas's. The first Catholic ward sister began her training in 1946, but was relegated to Hydestile, near Godalming, for several years before returning to $\mathrm{St}$ Thomas's. Roy Wake, The Nightingale Training School: 1860-1996 (London: Haggerston Press, 1998), 68, 171. Hydestile was used as a country hospital from 1940 to 1968.

${ }^{65}$ The Nursing Record \& Hospital World, 18 May 1895, 339.

66 'The Metropolitan Hospital Sunday Fund', Daily News, 16 December 1885.

${ }^{67}$ Parliamentary Papers, 392, Report from the Select Committee of the House of Lords on Metropolitan Hospitals (1890), 393, paragraph 6,661. At the London Hospital, nurses objecting to reading prayers could assign others to do it.

68 'The Nursing Question', Daily News, 16 December 1885.
} 
managed by the St John's House sisterhood) still 'obliged' nurse probationers to attend Anglican services regardless of their religious denomination. ${ }^{69}$ St Thomas's nursing staff attended Sunday services and twice weekly sermons by the hospital chaplain. ${ }^{70}$ Similar religious impositions can be found outside London also. Henry Bonham-Carter's advice to J.E. Morgan regarding organising the nursing at the Manchester Infirmary included: 'Religion is not a bar, but Probationers are expected to attend Prayers and Chapel. ${ }^{71}$ It is not difficult to imagine that Jewish, Catholic, nonconforming and non-believing nurses may have chafed against these religious practices being part of the requirements of their employment into the $1960 \mathrm{~s}^{72}$

Like most voluntary hospitals, the UCH staff included an Anglican hospital chaplain, thus privileging the Anglican ethos of the daily life on the wards. ${ }^{73}$ He not only counselled, preached and performed religious services, but also monitored religious activities on the wards. He permitted and appointed visitors and provided and/or approved the books and tracts they read to patients. ${ }^{74}$ Presbyterian Church Elder Major General James H. P. Anderson queried whether non-Anglicans could become chaplains. ${ }^{75}$ The General Committee's reply was to point to the published rules, which indicated:

The Chaplain shall be a minister of the Church of England; he shall perform Divine service and preach a sermon in the Hospital every Sunday; he shall visit all the wards in the Hospital daily, and he shall attend specially at any other time on patients who may desire to receive his ministrations. ${ }^{76}$

The hegemony of the Church of England was embedded in UCH hospital structures since its inception in 1834. The chaplain's functions were considered integral to the daily life of the hospital, even in this so-called 'godless institution of Gower street'. This, of course, had historic precedence; chaplains had been members of hospital staff since medieval times. The centrality of this function had shifted after the Reformation, but there was no question that the chaplain was meant to reflect and enforce the national religiomoral ethos of a hospital. ${ }^{77}$

In moving from a 'nursing question' to a 'religious question', the definition of sectarianism becomes more complicated and vexing. UCH was not the only hospital that upheld exclusionary hiring practices. Protestant Christianity was entrenched in the daily life of hospitals through the reading of prayers on the ward, the (in some cases) compulsory attendance of services by staff and patients and the staffing of Church of England chaplains. Yet, these were not acknowledged as sectarian practices. Many felt

${ }^{69}$ Parliamentary Papers, 457 Second Report from the Select Committee of the House of Lords on Metropolitan Hospitals (1890-91), 403, paragraph 18, 795-811. By this time, the only Anglican sisterhood employed in a London hospital was the All Saints Sisters at UCH.

${ }^{70}$ Roy Wake, op. cit. (note 64), 45.

${ }^{71}$ LMA, H01/ST/NC/18/04/026, Draft letter from H.B.C. to [J.E. Morgan] dated 9 December 1864.

72 Summers, 'Frameworks', op. cit. (note 10), 230. Summers recalls being told that at both St Bartholomew's Hospital and St Thomas's Hospital prayers continued to be said in the wards into the 1960s. Patricia Walls and Rory Williams, 'Sectarianism at Work: Accounts of Employment Discrimination Against Irish Catholics in Scotland', Ethnic and Racial Studies, 26, (2003), 642.

$73 \mathrm{UCH}$, OFF/MIN/4/2 5 January 1861, 205. For more on the history of the hospital chaplain, read the first two chapters of Christopher Swift, Hospital Chaplaincy in the Twenty-first Century: The Crisis of Spiritual Care on the NHS (Farnham, Surrey: Ashgate, 2009).

${ }^{74} \mathrm{UCH}, \mathrm{OFF} / \mathrm{MIN} / 4 / 63$ December 1884, 1.

75 UCH, OFF/MIN 4/6 15 July 1885, 70; 'Obituary', The Times, 9 January 1895, 6.

${ }^{76}$ UCLA, College Collection A-D, 1879 Annual Report, 29.

77 Swift, op. cit. (note 73), 33-6. 
Christianity should be embedded in daily life in the hospital. One 'Hospital Physician' saw this debate on sectarianism in hospitals as one meant to diminish the role of Christianity in hospitals and a 'direct challenge to the religious feeling and good sense of the profession'. The Spectator noted that 'we seem actually jealous and hurt when its [Christianity] healing influence is brought to beds of sorrow and suffering'. ${ }^{78}$ Potter, and others, spoke of the intrinsic nature of Anglican Christianity as unsectarian: 'the least sectarian arrangement in English hospitals was the moderate ascendancy of the services of the English Church'. ${ }^{79}$ This institutionalisation of Anglicanism was not simply linked to the religious proclivities of sisterhood nursing, or even female nurses. The movement from the 'nursing question' to the 'religious question' probed the underlying imbrication of the state church, or even Protestantism, within English hospitals.

\section{Hospital Funding}

The cry of 'sectarianism' became even more troublesome when it threatened the finances of voluntary hospitals. ${ }^{80}$ Nonconformist subscribers indicated their displeasure with UCH by threatening to cancel their subscriptions. Subscribers Mrs Madge and Miss Birchoff voiced their disappointment and informed the Committee that if nonconformists were not admitted as nurse probationers they would cancel their subscriptions. ${ }^{81} \mathrm{Mr}$ J. McLaren wrote that he would discontinue his subscription until 'present objectionable arrangements for nursing' were removed ${ }^{82}$ These letters generated fairly innocuous remarks in the UCH General Committee meeting minutes. ${ }^{83}$ Financially, annual subscriptions did drop from 1885 to 1886 , but only negligibly, from $£ 2,067$ to $£ 2,048$. The next year they increased to $£ 2,143$. These figures suggest that despite complaints, subscribers did not cancel their subscriptions. Donations, however, declined more significantly from $£ 7,177$ in 1885 to $£ 6,010$ the following year, but donation swings in both directions were typical in the 1880 s. Significantly, UCH held a fancy dress ball and bazaar in 1886 that was well-supported and generated an additional $£ 1,964 .{ }^{84}$ The governors of UCH in 1887 , commenting on the financial results of 1886, blamed their difficulties on the agricultural and industrial depression. ${ }^{85}$ While this may be true, it seems likely that the 'nursing question' had some financial effect on UCH. The support of the fancy dress ball and bazaar and subsequent upswings in subscriptions and donations reflect the short memories of UCH subscribers.

The Metropolitan Hospital Sunday Fund took the claim of sectarianism seriously; they feared it would damage the credibility of all voluntary hospitals and could lead to a decline in donations. Congregationist Minister Reverend Henry Allon (1818-92),

\footnotetext{
78 The Spectator, March 1886.

79 'The Question of Sectarian Nursing', The Lancet, 20 March 1886, 556.

${ }^{80}$ Mooney and Reinarz have argued that institutions guarded their good reputations, given the financial implications of bad press. Graham Mooney and Jonathan Reinarz, Permeable Walls: Historical Perspectives on Hospital and Asylum Visiting (Amsterdam: Rodopi, 2009), 15. Accusations that the German Hospital's Lutheran chaplain and deaconesses were proselytising Jewish patients resulted in a significant drop in subscriptions and donations in the 1890s. Swinbank, op. cit. (note 15), 128-30. Their restrictive hiring practices (they only employed Lutheran deaconesses as nurses) did not become an issue.

${ }^{81}$ UCLA, UCH OFF/MIN 4/6 October 1885, 84.

82 UCLA, UCH OFF/MIN 4/6 20 January 1886, 108-9.

83 The actual correspondence is not extant, but letters were excerpted in meeting minutes.

${ }^{84}$ UCLA, College Collection A-D, Annual Report 1886, 13, 17-32.

85 'University College Hospital' Charity Record \& Philanthropic News VII, 160, (7 April 1887), 117.
} 
a Metropolitan Hospital Sunday Fund Committee member, suggested that UCH should be denied a portion of fund donations due to its 'unsectarian' nursing practices. ${ }^{86}$ Allon and others feared this incident would 'imperil the harmony and efficiency of Hospital Sunday Fund' as the 'funds for building and supporting this particular hospital are obtained on the distinctive principles and assurance that no religious differences are permitted to affect its management'.87

Religious partisanship was an awkward issue as the Metropolitan Hospital Sunday Fund collected monies from over 1,800 churches and chapels of all denominations. In 1885, $£ 34,320$ was distributed based on hospital efficiency statistics such as cost per bed and the alleviation of disease. ${ }^{88}$ In 1885 , UCH received $£ 1,298$, eleven per cent of its total receipts. ${ }^{89}$ Despite the significance of the Hospital Sunday moneys to the UCH funding, meeting minutes do not register a concern about the potential disappearance of this source of funding. The Metropolitan Hospital Sunday Fund was more vocal with its fears, especially when Anglican clergy threatened to withdraw from the Fund. ${ }^{90}$ Such threats could imperil the financial success of the Metropolitan Hospital Sunday Fund. Their apprehension was not unfounded. The Lancet reported that, in Lincoln, nonconformist places of worship did not participate generously in hospital Sunday collections because the Lincoln County Hospital required that resident officers, nurses and servants were members of the Church of England. ${ }^{91}$ The Metropolitan Hospital Sunday Fund, according to minister John Oakley, was 'one of the few fields of united Christian enterprise in England', yet he ominously suggested: 'It must, if persisted in, raise the very undesirable question of proportional representation on the council of the Fund. ${ }^{\prime 2}$ He was reminding the Metropolitan Hospital Sunday Fund Committee that the Church of England collections represented the highest proportion of the receipts. H.G. Dickson called the Metropolitan Hospital Sunday Fund 'a great Church of England charity by which all denominations benefit', indicating that he believed that Anglican donations sustained the Fund. He commented that if UCH was exempted because it employed an Anglican sisterhood, then 'Was anything more suicidal ever proposed?'. He hinted that churchmen 'would take care of that' and the Metropolitan Fund would see reduced financial contributions from Anglicans as well as a tarnished reputation. ${ }^{93}$

Debates on the Sunday Fund's involvement in the internal affairs of hospitals were divisive. Some hoped the Fund would influence and reform the activities of hospitals. ${ }^{94}$

\footnotetext{
${ }^{86}$ Allon was the Congregationalist minister at Union Chapel, Islington, from 1844 until his death in 1892. Elaine Kaye, 'Allon, Henry (1818-92)', Oxford Dictionary of National Biography (Oxford University Press, 23 September 2014 online version).

87 'University College Hospital and the Hospital Sunday Fund', The Times, 3 August 1885, 4.

88 'Hospital Sunday Fund', The British Medical Journal, 19 December 1885, 1178.

${ }^{89}$ UCLA, College Collection A-D, 1886 Annual Report, 17, 32.

90 'The Nursing Question', The Times, 19 December 1885, 12. Also, 'Metropolitan Hospital Sunday Fund', The Lancet, 5 August 1885, 264. The Council of the Metropolitan Hospital Sunday Fund had received numerous letters containing protests and intimations of withdrawal from the Fund from nonconformist ministers.

91 'The Hospital Sunday Movement', The Lancet, 11 February 1871, 201.

92 'The Nursing Question', The Times, 11 August 1885, 3. Oakley (1834-90) defended the ritualist S.F. Green. C. W. Sutton, 'Oakley, John (1834-90)', rev. G. Martin Murphy, Oxford Dictionary of National Biography (Oxford University Press, 2004 online version).

93 'The Nursing Question', The Times, 8 August 1885, 11. Keir Waddington has noted that 'no other denomination could rival its influential position'. In $1895,84 \%$ of the contributions came from the Church of England. Waddington, op. cit. (note 17), 67-8.

94 Waddington, op. cit. (note 17), 145-6. Waddington writes about the transition of the Sunday Fund from a reforming body to a funding body.
} 
Others felt the Sunday Fund should not look into issues such as the 'minor matters of administration' or 'creeds of medical or nursing staffs' as this was beyond its capabilities and staffing. ${ }^{95}$ The predicament was that many voluntary hospitals imposed restrictive hiring practices. Roman Catholic and Jewish hospitals also imposed religious restrictions in their hiring of nurses and they received funds from the Metropolitan Hospital Sunday Fund. Tottenham Hospital's nurses were required to be evangelical Protestants and the German Hospital nurses were Lutheran deaconesses. ${ }^{96}$ They also received funding from the Metropolitan Hospital Sunday Fund. Allon countered that while Jewish and Roman Catholic hospitals held explicit religious identities, UCH, like most voluntary hospitals, publicly maintained no denominational identity. Most pertinent though, was that if the Metropolitan Hospital Sunday Fund adjudicated against UCH, it would likely have to address the 'sectarian' nature of other London voluntary hospitals. Of the nineteen general hospitals awarded funds, eight of them were nursed by women belonging to Protestant or Roman Catholic religious communities. ${ }^{97}$ Edward H. Sieveking MD (1816-1904) argued if

the authorities of the Sunday Hospital Fund are to exercise any control over the manner in which the nursing is carried on in the hospitals for which the public contribute strikes at the independence of these institutions to an extent which no body of governors could submit to. It is entirely for them to determine how their hospitals are to be conducted, and if they once admitted any authoritative interference on the part of the Sunday Fund Committee in nursing, we should expect shortly to hear of conditions with regard to the structure of our hospitals, the appointment of our chaplains, the food and beverage of our patients. . . 98

Sieveking suggested that the Sunday Fund's function as a reforming body would be onerous and impractical. ${ }^{99}$ In the end, the Metropolitan Hospital Sunday Fund, not wanting to weigh in on defining and sanctioning 'sectarian' practices, decided to remain 'a collecting body' rather than an interventionist organisation. The Council, which included representatives of various religious denominations, claimed that as these issues did not concern the patient, they were 'indisposed to interfere'. ${ }^{100}$ This decision is characteristic of Morris's contention that cultural and philanthropic arenas of interaction could become neutral areas when the edict of 'no religion, no politics' was followed. ${ }^{101}$ By stepping aside from the controversy, the issue of 'sectarianism' remained unrevolved. The Lancet was not

95 'University College Hospital and the Hospital Sunday Fund', The Times, 4 August 1885, 9.

96 Carmen M. Mangion, 'No nurses like the deaconesses?: Protestant deaconesses and the medical marketplace in late nineteenth-century England', in Susanne Kreutzer and Karen Nolte (eds), Deaconesses in Nursing Care: International Transfer of a Female Model of Life and Work in the 19th and 20th Century (Stuttgart: Franz Steiner Verlag, 2016), 161-84.

97 'Metropolitan Hospital Sunday Fund', The Lancet, 5 August 1885, 265. University College Hospital, Charing Cross Hospital, Royal Free Hospital, the German Hospital and Tottenham Training Hospital were nursed by Protestant sisterhoods, deaconesses or other religious bodies. The French Hospital and St John and St Elizabeth's Hospitals were nursed by Catholic religious congregations.

98 'The Nursing Question', The Times, 6 August 1885, 3. Edward H. Sieveking founded a children's hospital in Hamburg with his maternal aunt, Amelia Wilhelmina Sieveking (1794-1859), nursing reformer and founder of a deaconess community. He returned to England and in 1851 joined St Mary's Hospital in Paddington. Michael Anthony Waugh, 'Sieveking, Sir Edward Henry (1816-1904)', Oxford Dictionary of National Biography (Oxford University Press, Sept 2004 online version).

99 Waddington, op. cit. (note 17), 79. This shift from reforming to funding body continued into the twentieth century.

100 'Sectarian Nursing', The Lancet, 8 August 1885, 248.

101 R.J. Morris, Class, Sect, and Party: The Making of the British Middle Class: Leeds, 1820-50 (Manchester: Manchester University Press, 1990), 277. 
impressed. They encouraged nonconformists and others to 'fight the battle in individual hospitals'. ${ }^{102}$

The Hospitals Association and the Metropolitan Hospital Sunday Fund took the threat of a decline in contributions seriously. The debates highlight the tensions arising from the financial hegemony of the Church of England with regard to Sunday Fund contributions. Expanding the definition of sectarianism to include nurse-hiring practices was dangerous to future contributions, especially those arising from Anglican parishes. The practicalities of identifying exclusionary nursing practices could have meant the end of the Metropolitan Hospital Sunday Fund. It was easier and less controversial to define sectarianism with reference to patients' religious freedom than to consider the uncomfortable expansion (and financial implications) of defining sectarianism through religious activities in hospital spaces or hiring practices.

\section{Conclusion}

This article illustrates the contradictory understandings of sectarianism in institutional cultures in late-nineteenth-century England. When University College Hospital was accused of sectarianism, it responded by defining sectarianism as a patient's freedom to choose their own religious minister and practice their faith, focusing on institutional safeguards against proselytisation. This patient-centred definition suggested that sectarianism was freedom of religion, not freedom from religion. The surveys completed as a response to the UCH furore indicated that, in numerous voluntary hospitals, nursing staff and sometimes medical staff and patients were obligated to participate in Christian religious prayers and services. They, and other sources, suggest that privileging of particular denominations, particularly the Church of England, was embedded in hospital practices as well as nurse-hiring policies. When accusations of sectarianism threatened hospital finances, the Metropolitan Hospital Sunday Fund, with the support of the Hospitals Association, opted out of defining sectarianism and supported 'tolerable intolerance' in order to maintain their role in the funding of voluntary hospitals. Such religious institutional practices lasted long after the All Saints Sisters left UCH in 1898. They were replaced by nurses who belonged to 'no sectarian organisation'. Ironically, these nurses in this 'godless institution of Gower street', said prayers communally each morning and evening in the dining room of the hospital. They participated in prayers on the wards and in the chapel until at least $1938 .{ }^{103}$ These 'new nurses' were given a public religious voice in the wards that the All Saints Sister-nurses were denied. This begs the question as to whether the 1885 incident reflected the politics of Anglo-Catholicism and the divisiveness of Anglican sisterhoods rather than the actual religious practices on the wards.

The broader debates that arose from the threat of 'sectarianism in hospital' uncover the extent to which religious practices were ingrained in hospital spaces throughout England and remained so long afterwards. Despite the increasing medicalisation and secularisation of hospital spaces, religious practices and symbols were embedded in the daily life of voluntary hospitals. Hospitals were not simply medical institutions; they were social institutions that reflected the values of Victorian England. The place of religion in hospital

102 'Sectarianism in Nursing', The Lancet, 3 May 1890, 981. The nonconformists in Bath did just that in 1890 when an advertisement for a nurse required that she be a member of the Church of England. 'Sectarianism in Hospitals', The Lancet, 5 April 1890, 783.

${ }^{103}$ Likeman, op. cit. (note 21), 55 and 111-2. 
daily life was not merely incidental. It did not come and go with nurses or lady visitors whose femininity identified them as capable of transforming hospitals into places which disseminated moral and religious teaching. ${ }^{104}$ Male governors, administrators and medical staff upheld and even promoted a persistent religious ethos, in this case an Anglican one, underpinning hospital practices. The Victorian understanding of 'unsectarian' saw the Christian faith as a natural part of their cosmology, both integrated and integral to the patient experience in the late nineteenth-century English voluntary hospital.

104 Tanner, op. cit. (note 47), 81-110. 